\title{
Os sons do silêncio: interpelaçōes feministas decoloniais à história da historiografia
}

\author{
The sounds of silence: decolonial feminist inquiries to History of \\ historiography
}

\section{Maria da Glória de Oliveira}

\section{RESUMO}

Neste artigo proponho uma reflexão acerca da invisibilidade das produções de autoria feminina na história intelectual, tendo por horizonte alguns desafios postos pela perspectiva feminista decolonial. Como ponto de partida, abordo a separação paradigmática que se manifesta nas variadas formas de silenciamento acerca das contribuições intelectuais das mulheres por conta da persistência de um modelo de pesquisa com foco predominante no estudo dos repertórios canônicos de obras de autoria masculina, branca e europeia. $O$ argumento a ser explorado é o de que a produção de autoria feminina não se configurou como tema privilegiado e frequente da história da historiografia, mantendo-se, em larga medida, como o "outro" silenciado, marginal e periférico nos cânones historiográficos e na memória disciplinar. Por fim, defendo a efetividade da categoria de gênero como aparato conceitual crítico dos fundamentos epistêmicos da disciplina e da escrita da história, tais como a "irrelevância" dos marcadores de sexo, de raça e de classe social do sujeito da operação historiográfica, implícito nos critérios supostamente neutros, objetivos e universais de racionalidade.

\section{PALAVRAS-CHAVE}

História intelectual; Produção intelectual feminina; Gênero.

\section{ABSTRACT}

The article aims to reflect upon the invisibility of the productions of female authorship in intellectual history, based on some of the challenges posed by the decolonial feminist perspective. As a starting point, I approach the paradigmatic separation manifested in the various forms of silence regarding the intellectual contributions of women, due to the persistence of a research model with a predominant focus on the study of the canonical repertoire of works by male, white and European authors. The argument to be explored is that female intellectual production has not been configured as a privileged and frequent theme of intellectual history, remaining largely as the silent, marginal and peripheral 'other' in the historiographic canons and the disciplinary memory. Finally, I point to the effectiveness of the gender category as a critical conceptual apparatus of the epistemic foundations of the discipline and of the writing of History, such as the "irrelevance" of sex, race and social class makers of the subject of the historiographical operation, implicit in the supposedly neutral, objective and universal criteria of rationality.

\section{KEYWORDS}

Intellectual history; Female intellectual production; Gender. 
Não é fácil escrever esta carta. Começou como um poema, um longo poema. Tentei transformá-la em um ensaio, mas o resultado ficou áspero, frio. Ainda não desaprendi as tolices esotéricas e pseudo-intelectualizadas que a lavagem cerebral da escola forçou em minha escrita. [...]

As escolas que frequentamos, ou não frequentamos, não nos ensinaram a escrever, nem nos deram a certeza de que estávamos corretas em usar nossa linguagem marcada pela classe e pela etnia (ANZALDÚA 2000).

Maria-Nova olhou novamente a professora e a turma. Era uma História muito grande! Uma história viva que nascia das pessoas, do hoje, do agora. Era diferente de ler aquele texto. Assentouse e, pela primeira vez, veio-lhe um pensamento: quem sabe escreveria esta história um dia? Quem sabe passaria para o papel o que estava escrito, cravado e gravado no seu corpo, na sua alma, na sua mente (EVARISTO 2017).

As palavras acima são de autoras com obras e trajetórias de vida bastante distintas. A primeira, de ascendência mexicana, natural da fronteira do sul do Texas, viveu entre 1941 e 2004 e tornou-se referência no debate sobre a diferença interseccional no feminismo desde os anos 1980 no contexto norte-americano (KEATING 2009, p. 8). A segunda, brasileira, nascida em uma favela da zona sul de Belo Horizonte, trabalhou como empregada doméstica até concluir o curso normal, tornou-se mestre e doutora em Literatura e, recentemente, disputou uma vaga na Academia Brasileira de Letras (BETIM 2018).

Detenho-me inicialmente na citação de Conceição Evaristo, extraída do romance autobiográfico Becos da memória, publicado em 2006, em que a narradora-personagem MariaNova, menina negra, moradora da favela, busca o sentido para uma aula de História. O texto que a professora a faz ler sobre o passado do Brasil escravocrata lhe parece distante e abstrato demais porque difere daquilo que estava "escrito, cravado e gravado no seu corpo, na sua alma, na sua mente". A cena expressa, com muita clareza, uma relação de diferença: a história ensinada a Maria-Nova não é a mesma história que ela vive. Por isso, a menina imagina que, um dia, colocará no 
papel "uma história viva" e, neste caso, não se trata apenas de reescrever aquela história ensinada. A proposta de uma "escrevivência", tal como definida por Evaristo, tenta romper com a quebra entre o tempo da narrativa e o tempo da vivência, o que implica a ressignificação da própria noção de escrita (EVARISTO 2017, p. 9-11).

Poucas autoras transgrediram tanto na prática de gêneros textuais híbridos e indisciplinados quanto Gloria Anzaldúa. O trecho da epígrafe é uma passagem da "Carta às mulheres escritoras do terceiro mundo", publicada originalmente em 1981, na qual ela se dirige às "queridas mulheres de cor", explorando os desafios e os riscos que a escrita representa, porque, em suas palavras, "os olhos brancos não querem nos conhecer". Pela mesma razão, era "preciso uma enorme energia e coragem" para resistir a uma concepção de feminismo que, paradoxalmente, ainda tornava a maioria das mulheres invisíveis (ANZALDÚA 2000, p. 229). Sendo também a estratégia de sua obra mais célebre, Borderlands/La frontera: the new mestiza (1987), a forma mista do texto, que inicia como carta, mas se desdobra, por vezes, como autobiografia, poesia, diário e relato confessional, funciona como "mediação tradutória" de um complexo identitário em que se entrecruzam a condição de mulher, chicana, mexicana, lésbica, americana, escritora, militante e acadêmica da autora (BUTLER 2008, p. 228).

Com a leitura de Anzaldúa e de Evaristo é impossível não lembrar a paradigmática interrogação sobre a possibilidade da fala - e da escrita - dos sujeitos periféricos, lançada por Gayatri Spivak em 1985. ${ }^{1}$ Recentemente, o escritor Júlian Fúks evocou essa indagação no prólogo do livro Jamais o fogo nunca, da chilena Diamela Eltit, do qual também foi tradutor:

[...] esse sujeito tantas vezes silenciado não pode senão falar. A voz que fala para preencher o silêncio, a voz que outros quiseram silenciar, não poderia ser diferente, é a voz de uma mulher. A narradora inominável não pôde falar durante décadas - durante séculos, durante milênios, o tempo aqui se alonga sem limite discernível - ou ao menos não pôde ser ouvida, ninguém a quis ouvir. Não surpreende que seu tom esteja agora carregado,
1 - Refiro-me ao artigo "Pode o subalterno falar?", publicado inicialmente no periódico Wedge, em 1985, e com edição posterior em 1988, na coletânea Marxism and the interpretation of culture, organizada por Cary Nelson e Larry Grossberg (SPIVAK 2014, p. 12). 
de uma só vez, paradoxalmente, de dor e de indolência. [...] Seu corpo foi tomado de assalto pelo conjunto da sociedade, suas células já não lhe pertencem [...]. O próprio tempo não Ihe pertence - tudo o que lhe resta é a voz, a possibilidade de indagar o passado com obstinação e de ocupar com palavras o presente (FÚKS 2016).

A despeito de expressarem certo otimismo próprio de alguém que seguramente nunca experimentou a condição de "sujeito subalterno historicamente emudecido" (SPIVAK 2014), as contundentes palavras de Fúks também parecem ser feitas sob medida para descrever o que fazem outras tantas narradoras quando deixam de ser "inomináveis", a exemplo de Evaristo na escrevivência de suas histórias e da chicana Anzaldúa com a sua consciência mestiça, seu hibridismo textual e identitário.

As vozes dessas autoras condensam as interpelações às quais que se refere o título deste artigo. São interrogações que emergem na confluência de debates que, desde meados dos anos 1980, aproximam o pensamento feminista, as questões de gênero e a crítica pós-colonial. ${ }^{2}$ Tributária dessas inflexões, a proposta de um feminismo decolonial baseia-se na vinculação categórica entre raça e gênero, pressupondo "uma forma de compreender a opressão das mulheres subalternizadas através de processos combinados de racialização, colonização, exploração capitalista e heterossexualismo" (LUGONES 2014, p. 940-941). ${ }^{3}$

Nas reflexões que desenvolvo a seguir, a teoria feminista decolonial não estará propriamente no centro da análise, mas servirá como uma espécie de moldura e horizonte crítico para a compreensão da invisibilidade das mulheres como intelectuais. A constatação que tomo como ponto de partida é a de que, em suas diferentes abordagens, a história intelectual, incluindo a história da historiografia, ${ }^{4}$ não fala sobre gênero, mantendose alheia ao que, nos termos propostos por Joan W. Scott há mais de 30 anos, deveria ser uma categoria útil para a análise histórica. Esse silêncio talvez contribua, de modo persistente, para reforçar a pouca centralidade das obras de autoria feminina (ou de autores "outros") como objetos potenciais
2 - Sobre as articulações entre teorias críticas feministas e pós-colonialismo, ver BAHRI 2013; ALMEIDA 2013; BALLESTRIN 2017 e WALSH 2018. 3 - Em diálogo com
a noção de coloniali-
dade do poder (QUI-
JANO 2000), para a
pensadora argentina
Maria Lugones, o sis-
tema de colonialida-
de, construído histo-
ricamente a partir da
colonização europeia,
não se refere apenas
a um domínio sobre
uma suposta classifi-
cação racial, mas per-
meia todo o controle
imposto sobre o sexo,
as subjetividades, a
autoridade e o conhe-
cimento.

4 - Ao longo do artigo, usarei a expressão "história intelectual" em sua acepção mais ampla para designar o campo de estudos cuja pretensão é "interpretar e situar as obras intelectuais no tempo e inscrevê-las no cruzamento de duas linhas de força: uma vertical, diacrônica, por meio da qual se relaciona um texto ou um sistema de pensamento a atividades culturais precedentes [...] e a outra, horizontal, sincrônica, por meio da qual se estabelecem relações entre o conteúdo da produção intelectual e os outros domínios em uma mesma época" (SCHORSKE apud DOSSE 2010, 
desses estudos (SMITH 2007). O argumento que pretendo explorar é o de que as produções intelectuais femininas não se configuraram como tema privilegiado da chamada história das mulheres, nem da história intelectual, mantendo-se, em larga medida, como o "outro" silenciado pelos cânones e pela memória disciplinar. ${ }^{5}$

\section{A separaçāo paradigmática}

Em artigo instigante, intitulado "Women intellectuals and Intellectual history: their paradigmatic separation", a historiadora norte-americana Hilda Smith (2014) chamou a atenção para as variadas formas de exclusão que explicariam - silenciamento acerca das contribuições específicas das mulheres, derivadas de um modelo de história intelectual com foco predominante no estudo dos repertórios canônicos de obras de autoria masculina e de instituições acadêmicas que, tradicionalmente, vetaram a participação feminina em seus quadros. A partir desta constatação, talvez não seja exagerado falar em uma condição historicamente marginal e periférica das mulheres no campo da história intelectual.

Um olhar mais focado na história da historiografia evidencia que, a despeito de certa expressividade mais recente, não faltam evidências da escassez e da pouca centralidade dos estudos sobre as historiadoras, a começar por obras de síntese importantes que propõem balanços bibliográficos sobre a vida e obra de nomes canônicos, predominantemente homens. Entre alguns exemplos conhecidos, estão as coletâneas organizadas por Michel Vovelle (2005) e por Véronique Sales (2011). No Brasil, com proposta editorial similar, chama a atenção o projeto monumental, coordenado por Maurício Parada, intitulado Os historiadores e que, até o momento, já disponibilizou quatro volumes de ensaios, somando cerca de 60 capítulos, dedicados a autores "clássicos" da historiografia, desde a Antiguidade até o contexto atual, nos quais nenhuma autora/historiadora foi incluída. O mesmo acontece com a coletânea Grandes p. 379-380). A partir dessa concepção, a história da historiografia pode ser compreendida como uma modalidade específica de história intelectual que abarca a "investigação acerca das condições de emergência dos diferentes discursos sobre o passado", pressupondo a historicidade das práticas de pesquisa e de escrita da história, além de tomar essas práticas como efeito de disputas entre memórias coletivas e formas de atribuição de sentido à experiência do tempo (GUIMARÃES 2003, p. 23-24). Para uma discussão sobre história da historiografia como campo de pesquisa e gênero de escrita da história, ver TURIN 2013.

5 - Aplicada à história, a noção de cânone pode ser compreendida como a configuração de uma grande narrativa sobre o campo disciplinar que consiste na seleção de eventos, personagens, ideias, valores, autores e obras e que funciona como relato identitário e fundacional (GREVER; STUURMAN 2007, p. 3). 
nomes da história intelectual, organizada por Marco Antônio Lopes (2003). Da mesma editora, outra coletânea intitulada 50 grandes pensadores da História, curiosamente, desponta como exceção entre as demais publicações, por incluir em seu sumário, capítulos dedicados a três autoras: as norteamericanas Natalie Zamon Davis e Joan W. Scott e a inglesa Sheila Rowbotham. ${ }^{6}$

Recentemente, Daniel Woolf (2014) propôs uma história do pensamento histórico e da escrita da história a partir de uma perspectiva global e transnacional capaz de dar conta de "modos alternativos de historicidade" para além dos modelos dominantes ocidentais. É curioso observar que, a despeito de todas as inegáveis virtudes do projeto quanto a se mostrar explicitamente "inclusivo" em seu esforço por abordar as historiografias indiana, chinesa, mongol e islâmica, a história global da historiografia de Woolf reproduza o silêncio tradicional quanto às contribuições outras que não sejam as dos nomes e obras de autoria masculina. Ao longo de mais de 600 páginas, em Uma História global da história encontramos uma "caixa" à margem do corpo do texto principal sobre "as mulheres e a história na Europa renascentista" e três páginas apenas dedicadas à "História das mulheres e gênero, do século XIX ao presente", no capítulo final do livro.

No contexto acadêmico brasileiro, é possível atribuir a proliferação de projetos editoriais centrados nas obras dos historiadores à expansão renovada da produção na área da história intelectual, da história da historiografia e da teoria da história nos últimos 20 anos. ${ }^{7}$ Portanto, seria oportuno indagar se a consolidação desse campo de estudos representou algum avanço quanto à revisão crítica dos padrões predominantes de exclusão das contribuições intelectuais das historiadoras e de sujeitos "outros" que, tradicionalmente, permanecem invisíveis e marginalizados nos processos de construção dos cânones historiográficos.

Um levantamento rápido na revista História da Historiografia, observatório privilegiado das pesquisas recentes da área, aponta para um desequilíbrio de gênero quanto às autorias
6 - Ana Carolina Barbosa Pereira (2018) também apresenta balanço semelhante para as obras e autores da área da teoria da história que configurariam as narrativas fundacionais de institucionalização da disciplina.

7 - Indicadores importantes dessa renovação estão na realização do Seminário Brasileiro de História da Historiografia, que, neste ano de 2018 , completa a sua décima edição; na fundação da Sociedade Brasileira de Teoria e História da Historiografia (SBTHH), em 2009, e na criação das revistas História da Historiografia, Teoria da História, Expedições, Intelligere - Revista de História intelectual, entre outras; além da constituição de diversos núcleos de pesquisa e linhas de investigação vinculadas a Programas de Pós-graduação espalhados pelo Brasil. Para um balanço crítico recente, ver ARAÚJO 2017. 
de trabalhos. Em seus 26 números, apenas 124 textos são assinados por mulheres, o que corresponde a $29 \%$ do total de 422 artigos e resenhas publicadas ao longo dos 10 anos de existência da revista (2008 a 2018). Quando consideramos os títulos e temas dos artigos, chama a atenção que, desse total de publicações, apenas cinco artigos contemplam estudos sobre a obra e a trajetória de autoras e/ou historiadoras, sendo predominantes os estudos em torno de nomes masculinos canônicos da historiografia geral, como Michel de Certeau, Lucien Febvre, F. Braudel, e da historiografia brasileira, como Francisco Adolfo de Varnhagen, Capistrano de Abreu e José Honório Rodrigues. ${ }^{8}$

A hipótese mais imediata para esse quadro poderia ser a de que as discrepâncias de gênero, tanto no indicador de autoria, quanto no de temas e objetos indicados nos títulos, talvez correspondessem a um número desigual de pesquisadores homens e mulheres na área de história da historiografia. De fato, considerando os dados referentes ao total de membros cadastrados na Sociedade Brasileira de Teoria e História da Historiografia (SBTHH), observa-se que dos 614 associados efetivos até maio de $2018,39 \%$ são mulheres frente a $61 \%$ de homens, o que, a princípio, demonstra certo desequilíbrio de gênero na composição da área de pesquisa em teoria e história da historiografia. ${ }^{9}$ Os dados sugerem que essa desproporcionalidade não acompanha a distribuição equilibrada entre homens e mulheres com titulação de mestrado e doutorado na grande área da história no Brasil, conforme apontam levantamentos mais recentes. ${ }^{10} \mathrm{O}$ relativo equilíbrio no acesso à formação acadêmica não deve mascarar, contudo, as desigualdades de gênero estruturais que estão na base do que Pierre Bourdieu (2017) chamou de "coeficiente simbólico negativo" das mulheres. Tais assimetrias escapam, em geral, a uma apreensão quantitativa na medida em que podem se manifestar na distribuição tácita de "tarefas" dentro de uma mesma área disciplinar, segundo princípios historicamente discriminatórios, e ainda vigentes, que costumam conceder "aos homens o mais nobre, o mais sintético, o mais teórico e às
8 - o levantamento considerou os 26 números da revista, publicados entre 2009 e 2018 e disponíveis no site https://www.historiadahistoriografia. com.br/revista/issue/ archive.

9 - Dados fornecidos pela secretaria da SBTHH. Evidentemente, trata-se de indicadores iniciais e, portanto, ainda insuficientes para uma radiografia fidedigna, o que demandaria levantamentos semelhantes em outros periódicos e a busca ampliada pela produção na área em bancos de teses e sites de programas de pós-graduação.

10 - Baseio-me nos dados recentes, divulgados em: https://www.nexojornal.com.brl grafico/2018/05/23/ Qual-o-gênero-e-a-idade-de-mestres-e-doutores-no-Brasil. Acesso em: out. 2018. 
mulheres o mais analítico, o mais prático, o menos prestigioso" (BOURDIEU 2017, p. 127). A força e o peso dessas injunções acrescentam variáveis nada desprezíveis ao problema da pouca visibilidade da produção intelectual feminina.

\section{Escrita "feminina"?}

Ouso da expressão"escrita feminina"conduzinevitavelmente a um território de ambiguidades e imprecisões nebulosas (BRANCO 1991, p. 12). Por um lado, não é difícil admitir que toda experiência histórica pode ser perpassada por clivagens de gênero, o que, recentemente, permitiu à vencedora do prêmio Nobel de Literatura, Svetlana Aleksiévitch (2016), escrever uma outra história da Segunda Guerra Mundial tomando por fio condutor os relatos de memória das mulheres que lutaram na linha de frente do exército russo. Por outro, torna-se cada vez mais difícil não admitir que a lógica binária de feminino/ masculino, homem/mulher, perdeu toda a sua estabilidade e autoevidência. A concepção unitária e genérica da categoria "mulheres" já foi alvo de desnaturalizações incontornáveis, como a do estudo célebre de Denise Riley sobre a sua construção ambígua pela própria história do feminismo (RILEY 1995).

É importante notar que, interrogadas sobre seus escritos, não são poucas as autoras que preferem desqualificar a questão, compartilhando a postura de negação da diferença quanto a uma modalidade de "literatura feminina" (RICHARD 2002, p. 131). Entre essas autoras está uma das figuras cuja obra costuma ser eleita como "fundadora" da história do feminismo, a inglesa Virginia Woolf. A autora de Um teto todo seu não negava que a escrita literária de uma mulher fosse feminina, mas tampouco perdia a oportunidade de fazer uma observação sarcástica sobre o assunto: "não pode deixar de ser feminina; nos melhores casos, é extremamente feminina; o único problema é [seria] definir o que se entende por 'feminina'" (WOOLF 2012, p. 29). A essa observação se poderia acrescentar 
o argumento de Hèlène Cixous de que a impossibilidade de delimitação de uma prática de escrita feminina não implica sua inexistência (CIXOUS apud SHOWALTER 1994, p. 29). A diferença estaria no estilo? No gênero textual? Na experiência? Ou seria efeito da recepção das obras, pelo processo de leitura? A recusa dessa pretensa especificidade, baseada, em geral, no argumento óbvio de que "a escrita não tem sexo", conviveu, no entanto, com a constatação de que os cânones literários sempre omitiram ou subestimaram o valor das obras de autoria feminina. A condição secundária e marginal desses escritos usualmente se reverteu sob duas condições: nos casos em que se promovem "resgates" de algumas autoras sob o pretexto paternalista de um falso reconhecimento; e também quando o próprio mercado editorial vislumbra o potencial diferenciado de consumo desse segmento da produção literária (RICHARD 2002, p. 128).

Não obstante os seus efeitos positivos para a superação do esquecimento e da invisibilidade frente aos cânones dominantes, a expressão "literatura de mulheres" baseiase no recorte essencialista que conecta sexo e identidade, o que inevitavelmente conduz à indagação acerca dos critérios possíveis para tipificar uma textualidade "feminina" de modo a sustentar o suposto vínculo diferencial entre condição sexual, gênero e escrita (RICHARD 2002, p. 138). Por outro lado, uma questão não menos relevante também estaria na própria concepção representacional da obra literária conforme a qual os textos espelhariam condições socioculturais, incluindo os atributos de sexo e gênero, de seus autores. Assim, por uma espécie de determinação anterior e externa às obras, a autoria feminina implicaria a expressão das singularidades do "ser mulher" como referentes naturais de uma essência identitária estável e passível de ser apreendida nos textos, assegurando a equivalência simplória entre "mulheres que escrevem" e "o escrever como mulher" (RICHARD 2002, p. 130). ${ }^{11}$

Em que medida é possível estender tais discussões, oriundas do campo da crítica literária feminista, e convertê-las

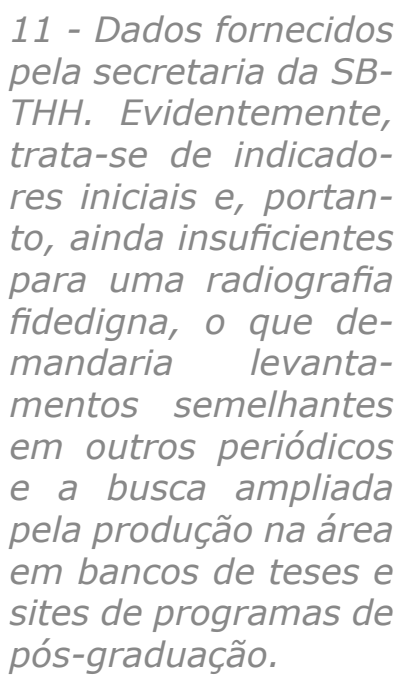
pós-graduação. 
em indagações sobre os modos como as mulheres escrevem ou praticam a história? Não se trata, neste caso, de adentrar na agenda de preocupações específicas dos estudos que alçaram as mulheres à condição de objeto de pesquisa e agentes históricos, mas de explorar a questão que não passou despercebida a Michel de Certeau quando refletia sobre o historiador e as suas relações com os outros sujeitos sobre os quais escreve: "[...] em decorrência da diferenciação entre os sexos, deve-se concluir que uma mulher produz uma outra historiografia que aquela do homem?" (CERTEAU 1987, p. 79). Lamentavelmente, o autor de $A$ escrita da História nos deixará sem a resposta, sugerindo, contudo, que a pergunta lança luz sobre os padrões epistemológicos e disciplinares que delimitam a "verdade" de um saber baseando-se na suposta irrelevância do lugar de seu autor. ${ }^{12}$

No Brasil, a incorporação da categoria de gênero nas disciplinas acadêmicas que compõem as ciências humanas e sociais ocorreu de modo desigual (HEILBORN; SORJ 1999) e, de acordo com balanços mais recentes, manteve-se como "mero complemento de temas e objetos tradicionais de estudo" (KÜCHEMANN; BANDEIRA; ALMEIDA 2015, p. 79)..$^{13}$ $O$ que interessa destacar aqui são os trabalhos nesse campo que contribuíram para reverter, ainda que timidamente, a invisibilidade da atividade intelectual feminina. É o caso do estudo inspirador de Marisa Corrêa, Antropólogas e antropologia (2003), cujo primeiro capítulo aborda o esquecimento da figura de Dina Lévi-Strauss, antropóloga, autora de Instruções práticas para pesquisas de antropologia física e cultural (1936), professora agregée da Universidade de Paris, que acompanhou o marido Claude Lévi-Strauss, em sua estadia no Brasil como professor contratado da Universidade de São Paulo. Na antropologia, salvo raras exceções, sobram exemplos de esposas antropólogas que, como Madame Lévi-Strauss, adotaram o sobrenome do marido. Dois exemplos conhecidos: Edith Turner, casada com Victor Turner, e Helen Pierson, esposa de Donald Pierson. Todas cumpriram um papel considerável de auxiliares de pesquisa de campo, segundo o relato de seus próprios parceiros, mas

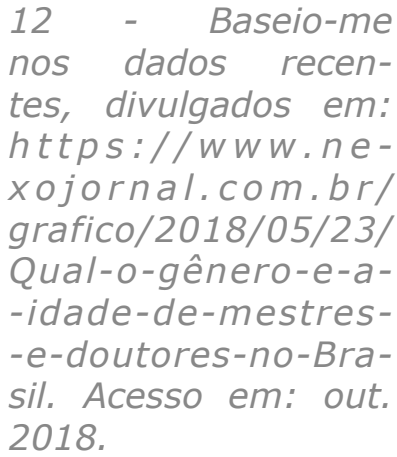

13 - Uma parcela da crítica feminista, sobretudo nos anos 1970 e 1980, tendeu a atribuir um papel transgressor e um potencial crítico à escrita feminina, justamente por ser uma prática situada às margens do controle simbólico masculino. No entanto, como observa a chilena Nelly Richard, a relação entre mulher e transgressão nunca pode ser estabelecida a priori, pois, para um texto ser portador de potencialidade transgressora, não basta ter sido "escrito por uma mulher". Ademais, "o 'ser homem' tampouco condena o sujeito-autor a ser fatalmente partidário das codificações de poder da cultura oficial [...]" (RICHARD 2002, p. 134-135). 
permaneceram à sombra, como personagens secundárias, se não inexistentes, na história da antropologia.

A relevância do trabalho de Correa reside justamente na reconstituição das trajetórias de três personagens femininas que não se enquadraram na categoria de "esposas de", papel supostamente "aceitável" das mulheres que cumpriam carreiras semelhantes às suas: a naturalista Emília Snethlage, a sertanista Leolinda Daltro e a pesquisadora Heloisa Alberto Torres, que seriam "exemplos quase do avesso do que era uma carreira bem-sucedida de suas contrapartidas masculinas" dentro do campo da antropologia nos anos 1940 e 1950 (CORREA 2003, p. 31). Na área da geografia, na sua tese, Patrícia Aranha (2017) problematizou igualmente o apagamento das mulheres da historiografia hegemônica da constituição da disciplina no Brasil, a despeito de as mulheres se constituírem como maioria nos cursos de graduação da área.

Em se tratando da história da historiografia, o sinal perceptível da separação paradigmática assinalada por Hilda Smith está no número ainda restrito de trabalhos que abordam as historiadoras e as suas produções historiográficas, comparativamente àqueles que tematizam historiadores. A notícia alentadora é a de que algumas boas exceções já aparecem no horizonte. Refiro-me às teses recentes de Carmem Liblik (2017), Uma história toda sua: trajetórias de historiadoras brasileiras (19341990), Octavio Erberele Junior (2016), A trajetória intelectual de Alice P. Canabrava (1935-1997) e Daiane Vaiz Machado (2016), Por uma "ciência histórica": o percurso intelectual de Cecília Westphalen, 1950-1998, que merecem destaque não somente pela qualidade e originalidade, mas por despontarem em um campo de investigação cuja renovação nas últimas décadas se evidenciou em pesquisas com foco predominante em trajetórias de historiadores e em produções intelectuais de autoria masculina. ${ }^{14}$

Por outro lado, o campo fértil da história social das mulheres e estudos de gênero, constituído no contexto dos movimentos feministas desde os anos 1970, conquistou a sua robustez

\begin{abstract}
14 - No campo de pesquisas sobre a história do feminismo, destacam-se os estudos das trajetórias de militantes feministas brasileiras. Entre os mais recentes, cabe mencionar a pesquisa de Natalia Pietra Mendez (2018), Intelectuais feministas no Brasil dos anos 1960: Carmen da Silva, Heleieth Saffioti e Rose Marie Muraro.
\end{abstract}


institucional com uma produção acadêmica hoje consolidada. ${ }^{15}$ Ninguém mais duvida de que as mulheres possuem a sua própria história e de que a escrita dessa história seja capaz de "iluminar e sofisticar a História dita geral", como afirmam Carla Pinsky e Joana Pedro na apresentação da obra coletiva Nova História das mulheres, publicada em 2013 (PINSKY; PEDRO 2013, p. 10). Nesse conjunto vasto de estudos, observa-se, contudo, que o "feminino" aparece vinculado, de modo majoritário, às temáticas do corpo, da sexualidade, da maternidade, da família e do cotidiano e, raramente, às atividades letradas e intelectuais. ${ }^{16}$

Coube, em grande parte, aos estudos literários retirarem do esquecimento a produção intelectual e letrada de autoria feminina, especialmente a do Brasil do século XIX, por meio de dissertações, teses, artigos e da elaboração de antologias e dicionários biográficos. Neste caso, foram duas referências obrigatórias que inauguraram esses estudos nos anos 1980: a tese de Norma Telles (2012), sobre escritoras e imaginação literária no Brasil, de 1987, e a de Maria Thereza Caiubi Bernardes, de 1988, centrada nas mulheres de letras no Rio de Janeiro, no século XIX. ${ }^{17}$

Nos anos 1990, destacam-se os projetos de Heloísa Buarque de Hollanda e Lúcia Nascimento Araújo (1993), Ensaístas brasileiras, com o levantamento das mulheres que escreveram sobre literatura e artes entre 1860 e 1991 . Entre as antologias, a referência principal está na obra em três volumes, resultado de um trabalho de pesquisa coletiva, realizada entre 1999 e 2004, coordenado por Zahidé Muzart e que tirou do esquecimento os nomes de 104 escritoras brasileiras do século XIX. Ainda para esse contexto, na publicação recente do dicionário da imprensa feminina e feminista no Brasil, de Constância Lima Duarte (2017), são listados 143 títulos de revistas e jornais femininos e feministas que circularam no Brasil no século XIX.

Em suma, poderia elencar aqui os centros e núcleos de pesquisa vinculados a departamentos e programas de pósgraduação como evidências da fecundidade e de uma bemsucedida institucionalização dos estudos feministas em literatura

\begin{abstract}
15 - Entre os indicadores mais evidentes da sua institucionalização, encontram-se as duas revistas acadêmicas, ambas vinculadas a programas de pós-graduação, Estudos Feministas, que circula desde 1992, e Cadernos Pagu, com publicação desde 1993.
\end{abstract}

16 - É o que demonstram os sumários $e$ índices temáticos dos cinco volumes de DUBY; PERROT (1991-92) e PRIORE (2004).

17 - Ainda nesse contexto, é importante considerar a criação do grupo de trabalho (GT) "Mulher na literatura" na Associação Nacional de Pós-graduação e Pesquisa em Letras e Linguística (ANPOLL), que, a partir de 1986, aglutinou um número expressivo de pesquisadore(a)s na área. 
no Brasil. O que talvez ainda mereça uma avaliação mais detida seria o uso transversal e interdisciplinar da categoria de gênero (PEDRO 2011), que comprometeria o alcance efetivo da sua potência crítica dentro do campo historiográfico. Ou, ainda, retomando a formulação de Heloísa Buarque de Hollanda para a crítica literária, caberia indagarmos acerca da "legitimidade ou da capacidade dos estudos feministas para oferecerem um novo corpus teórico e metodológico" (HOLLANDA; ARAÚJO 1993 , p. 29). E, neste caso, a observação também valeria caso existisse algo como uma crítica historiográfica como gênero similar ao do campo literário.

A separação paradigmática que circunscreve, de um lado, a história das mulheres e, de outro, a história intelectual e a história dos intelectuais, ultrapassa a questão das respectivas especificidades das agendas de pesquisa dessas áreas. ${ }^{18}$ Há 14 anos, na apresentação de uma obra coletiva sobre intelectuais francesas, Nicole Racine e Michel Trebitsch (2004) assinalavam que a introdução da perspectiva de gênero no campo da história intelectual significava um "elemento perturbador das classificações tradicionais", do foco e do ângulo de visão. A história intelectual, até então, era sobretudo uma história de intelectuais do sexo masculino e, por conta disso, o estudo das intelectuais sempre se constituiu, nas ciências humanas, em objeto e tema para especialistas em mulheres, gênero e feminismo. Por sua vez, em uma coletânea dedicada à história das historiadoras francesas, Nicole Pelegrin acrescentaria que o silêncio acerca da produção historiográfica de autoria feminina tem consequências teóricas consideráveis quanto à compreensão do próprio trabalho historiográfico, argumentando que "escolhas temáticas, opções metodológicas, formas narrativas, lugares de produção e de recepção dependem em grande parte do pertencimento social (de sexo e de classe) dos adeptos de Clio, assim como das conjunturas sociais mais amplas" (PELEGRIN 2006, p. 13).

Assim, o argumento mais imediato a ser destacado é o de que a ausência do uso da categoria de gênero nos estudos
18 - Para uma discussão sobre os campos da história intelectual e história dos intelectuais, sobretudo em sua configuração no contexto francês, ver DOSSE 2010. 
de história intelectual vincula-se, em grande medida, a certa partilha de temas, objetos e competências de pesquisa que tende a reproduzir interdições, vetos e constrangimentos que regem a dinâmica da produção do conhecimento disciplinado nas humanidades em geral. E, neste caso, não basta considerar as relações de gênero como elementos estruturantes das relações de poder, dos modos de funcionamento dos campos acadêmico e intelectual. Caberia avançar, de forma mais específica, na avaliação da efetividade da noção de gênero como aparato conceitual crítico dos fundamentos epistêmicos da disciplina e da própria escrita da história, a começar pela "irrelevância" dos marcadores de sexo, de raça e de classe social do narrador, ou seja, do sujeito da operação historiográfica, em nome de critérios supostamente neutros, objetivos e universais de racionalidade. ${ }^{19}$ Embora não seja novo, tal questionamento talvez mereça ser retomado, mesmo com todas as implicações advindas da recente problematização da categoria de gênero. Para tanto, uma opção seria tomar o conceito fora de qualquer presunção identitária essencialista ou, para usar os termos de Butler (2016), como uma espécie de dispositivo regulador histórica e temporalmente construído por meio de performances sociais repetidas que, de modo contínuo, tendem a constituir e a naturalizar um esquema binário sobre o que é ser feminino e o que é ser masculino.

Os processos de constituição disciplinar da história no século XIX foram notoriamente excludentes em relação à participação de historiadoras nos círculos historiográficos "profissionais". Ademais, até meados do século XX, essa construção "masculina" da disciplina reforçou a própria invisibilidade da dimensão de gênero dos fenômenos estudados (CHARPENEL 2018). O que talvez fosse importante explorar, considerando a história da historiografia, seriam os limites de certa constatação resignada, sobretudo para aqueles que estudam a cultura historiográfica brasileira no século XIX, de que não existiram mulheres historiadoras por conta da própria condição feminina na sociedade patriarcal, marcada pela falta de acesso amplo à educação, à cultura letrada e à formação

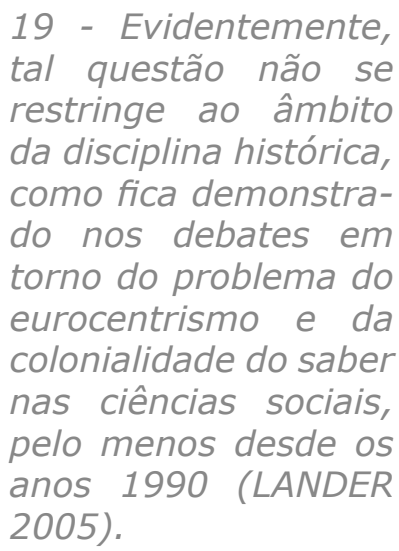

19 - Evidentemente, tal questão não se restringe ao âmbito da disciplina histórica, como fica demonstrado nos debates em torno do problema do eurocentrismo e da colonialidade do saber nas ciências sociais, pelo menos desde os 2005) 
profissional e, por conseguinte, pelas limitadas, se não nulas, possibilidades de inserção e atuação em agremiações, instituições e redes de sociabilidade acadêmicas (TELLES 2012, p. 75-83). Se, por um lado, o caráter excludente desse contexto não pode ser menosprezado, por outro, tampouco seria irrelevante lembrar que, no processo específico de disciplinarização do conhecimento histórico, o que era então reconhecido como "historiográfico" pressupunha uma circunscrição de gênero de escrita menos baseada em critérios vinculados a uma modalidade textual de contornos bem definidos e mais na autoridade daquele que a praticava, em grande parte, baseada no sexo, raça e classe social.

Como já demonstrado em estudos sobre as biografias de homens de letras publicadas na Revista do Instituto Histórico e Geográfico Brasileiro, as tarefas do historiador no Brasil imperial foram delimitadas a partir de um repertório de virtudes epistêmicas, cujas evidências seriam: (a) os usos das tópicas do amor à verdade, da abnegação e da imparcialidade, assinaladas nos elogios biográficos, designando virtudes inatas em certos homens de letras que funcionavam como índices reguladores no processo de institucionalização e profissionalização da pesquisa e da escrita da história no Oitocentos; (b) o louvor dessas virtudes - identificadas em outros tipos de discursos -, circunscrevendo parâmetros e padrões ideais de conduta baseados em qualidades e traços de caráter dos sujeitos letrados; (c) na constituição da historiografia dita "científica", as garantias de credibilidade das obras historiográficas estariam, portanto, na adequação desses sujeitos aos ideais de uma performance virtuosa do historiador. A ambicionada imparcialidade, para citar um exemplo de virtude epistêmica central para a história disciplinada, corresponderia mais a um conjunto de traços relacionados a competências intelectuais e atributos morais inatos a certos homens de letras do que aos efeitos da prática de um procedimento de investigação específico (OLIVEIRA 2010).

Em suma, ser historiador no século XIX era mais uma questão de índole cívica e disposição moral do que de método. 
Naquele contexto, para usarmos a chave explicativa historicista, ser historiadora implicaria uma flexão de gênero impossível, pois, excluídas do exercício da cidadania e do corpo político da nação, as mulheres estariam destituídas do próprio ethos que definia o historiador oitocentista (TURIN 2009), ou seja, dos atributos mínimos para a escrita da história. Acrescente-se a isso o fato de que a produção letrada de autoria feminina, mesmo aquela dotada de relativo reconhecimento entre os pares masculinos, era previamente demarcada por um tipo de recepção que a situava às margens dos cânones literário e historiográfico. Estariam lançadas aí, portanto, as bases de um apagamento duradouro que contribuiu para a naturalização da ideia de que as mulheres não produziam historiografia "profissional" ou qualquer outro gênero similar que pudesse ser reconhecido como relevante (SMITH 2003, p. 23-25).

Até mesmo quando se empenhavam na prática de um gênero socialmente recomendável para o sexo feminino como a poesia, as mulheres letradas não estavam de todo livres dos padrões de enquadramento crítico e estético que Ihes circunscrevia os limites e o próprio conteúdo da escrita. Foi assim com Narcisa Amália, a poetisa nascida no Rio de Janeiro na segunda metade do XIX, que ousou saudar os ideais libertários da Revolução Francesa em seu livro de poemas, intitulado Nebulosas, publicado em 1872. Naquele mesmo ano, a recepção favorável à autora não deixaria de vir acompanhada de objeções ao explícito engajamento de sua obra: "[...] perante a política, cantando as revoluções, endeusando as turbas, acho-a simplesmente fora de lugar"; estas foram as palavras da resenha assinada por Carlos Ferreira, no Correio do Brasil, recomendando que o "talento da ilustre dama" permanecesse "na esfera perfumada do sentimento e da singeleza", por ela não possuir "a virilidade necessária" para cultivar a poesia de cunho social (FERREIRA apud TELLES 2012, p. 422). ${ }^{20}$

Não foi muito diferente o argumento que justificou, em dezembro de 1850, o veto à primeira e única proposta de admissão de uma mulher no Instituto Histórico e Geográfico

\begin{abstract}
20 - É irrelevante, neste caso, avaliar o quanto foram consensuais ou não objeções como essas à obra da poetisa. Nas palavras de Telles, os comentários de Ferreira são suficientemente emblemáticos quanto ao "duplo padrão da crítica, isto é, critérios diferenciados para julgar ou comentar obras de homens e de mulheres" (TELLES 2012, p. 422).
\end{abstract}


Brasileiro (IHGB), tornando evidente que, naquele que era o lugar da memória e da história nacional, não havia espaço para representantes do sexo feminino, mesmo com virtudes letradas notórias, e menos ainda para a poesia.

A comissão encarregada de dar um parecer sobre a proposta, que apresenta, para ser admitida na classe dos membros honorários do Instituto Histórico e Geográfico Brasileiro a IIma. Sra. D. Beatriz Francisca de Assis Brandão, compreendendo também que muito se faz criar [sic] incentivos às nossas patrícias, receosas de se dar ao cultivo das letras, muito aplaudiu o generoso pensamento dos ilustres signatários da proposta, e examinando maduramente os estatutos e neles não encontrando disposição alguma relativa à matéria da proposta, tendo em devida atenção o princípio de que a lei tolera pelo menos aquilo que não proíbe, com a mais viva satisfação declara, que não se pode legalmente disputar às senhoras o direito de fazer parte desta importante associação [...] (SILVA 2005, p. 349, grifos meus).

A indicação do nome da poetisa nascida em Ouro Preto, que se tornara conhecida por seus versos impressos em jornais e no Parnaso Brasileiro, de Januário da Cunha Barbosa, havia sido uma iniciativa dos sócios Joaquim Norberto de Sousa Silva, seu irmão, João José de Sousa Silva Rio, e Luis Antônio de Castro. Autor da biografia de Beatriz Brandão, incluída na antologia Brasileiras célebres (1862), Norberto de Sousa Silva destacava que "a chama do amor à pátria" resplandecia em seus versos de "estilo brando e suave" (SILVA 2005, p. 346-347). O argumento da proposta baseava-se na recomendação de que o IHGB, na condição de "ilustre representante do movimento e do progresso das letras no Novo Mundo", honrasse "o talento e o mérito das senhoras brasileiras" acolhendo a "distinta poetisa, já reconhecida e estimada nos circuitos literários por suas composições", o que serviria de incentivo e estímulo a outras "patrícias receosas de se darem à cultura das letras e afrontar os preconceitos da nossa velha educação" (SILVA 2005, p. 349). ${ }^{21}$

Curiosamente, a comissão encarregada de avaliar a proposta era formada pelos literatos e poetas Joaquim Manoel de Macedo e Gonçalves Dias. Como se sabe, a instituição já
21 - É possível identificar nesta proposição o eco de vozes dissonantes que, naquele contexto, se não desafiavam mais incisivamente as constantes interdições institucionais, marcavam alguma posição na defesa da inserção das mulheres na "república das letras", a exemplo do próprio Norberto de Sousa Silva com o seu projeto de escrita de biografias de escritoras (SILVA 2005, p. 307358). 
agregava, em seus quadros, homens de letras com produção intelectual marcada por uma indisfarçável veia poética, a exemplo dos trabalhos da dupla mencionada. Isso se explica porque, de acordo com os Estatutos de 1851, o critério para ingresso no quadro de sócios efetivos do IHGB, assim como para o de correspondentes, consistia na comprovação da produção letrada, o que, naquele contexto, possibilitava a apresentação de obras de gêneros variados (incluindo memórias, crônicas, corografias, tratados, dissertações, biografias, elogios históricos, etc. ), como fica demonstrado no material estampado nas páginas da revista da agremiação ao longo do século XIX.

Ora, o caso da poetisa mineira deixa muito evidente que o mencionado critério da produção comprovada poderia não ser tão decisivo assim para a admissão de novos sócios. Basta lembrar que uma exceção anterior havia permitido, por exemplo, que Pedro Affonso de Figueiredo, barão de Wildik e cônsul-geral de Portugal no Rio de Janeiro, fosse admitido como sócio mediante a apresentação de um "Guia do cidadão português no Império do Brasil" como único comprovante de suas virtudes intelectuais (GUIMARÃES 1996, p. 487-488).

O que prevaleceu no argumento para a recusa do ingresso de Beatriz Brandão no IHGB, portanto, foi a orientação marcadamente androcêntrica da agremiação. Passados alguns anos do episódio, é o próprio Norberto de Sousa Silva quem reconhece que, se o Instituto não a havia admitido entre seus membros, não havia sido por falta de reconhecimento de seus méritos poético-literários (SILVA 2005, p. 349). É o que também fica explicitado no parecer de Macedo e Gonçalves Dias, quando alegam que o Instituto não era lugar para a "respeitável patrícia" e "distinta poetisa", recomendando, por fim, que ela fosse recebida "como ornamento de uma sociedade literária, cujos fins não estivessem limitados à história e à geografia" (REVISTA DO IHGB 1892, p. 71). Mais desfavorecida por pertencer ao gênero feminino e menos pelo gênero literário que praticava, talvez tenha faltado à poetisa, como bem notou Lúcia Guimarães, a intervenção de uma 
"força moral" para o ingresso na agremiação, expediente usado por Varnhagen quando apelou diretamente à recomendação pessoal do imperador para agilizar a admissão de Cândido Mendes de Almeida, "acolhido como sócio em um passe de mágica" (GUIMARÃES 1996, p. 489). ${ }^{22}$

Cerca de 60 anos após a criação do IHGB, no contexto da Primeira República, a criação da Academia Brasileira de Letras $(A B L)$ pouco contribuiu para quebrar a tradição sexista e androcêntrica que orientava as instituições acadêmicas no Brasil. Na instituição literária fundada, entre outros, por Machado de Assis e Lúcio Mendonça, a elegibilidade feminina, embora tenha sido pauta de debates acalorados em inúmeras sessões, manteve-se vetada nos primeiros 80 anos de sua existência. ${ }^{23}$ Até 1951, o Estatuto da Academia previa que apenas "brasileiros" que tivessem, "em qualquer dos gêneros de literatura, publicado obras de reconhecido mérito ou, fora desses gêneros, livro de valor literário" poderiam concorrer a uma de suas cadeiras (FANINI 2010, p. 149). Quando da primeira candidatura feminina, em 1930, Amélia Beviláqua foi rejeitada sob a justificativa de que o vocábulo "brasileiros" restringiria as vagas apenas ao sexo masculino, o que deixou bastante explícito que a Academia relacionava valor literário a gênero.

Por fim, caberia ainda uma observação sobre o caso Beatriz Brandão: o episódio ficou relegado às notas de rodapé dos estudos mais recentes de historiografia brasileira do século XIX (OLIVEIRA 2011), com exceção da menção feita no corpo do texto na tese de Lúcia Guimarães (1996, p. 489). A meu ver, isso comprova, em primeiro lugar, a eficácia e a infalibilidade do trabalho de esquecimento e de apagamento disciplinar na naturalização dessa e de outras formas de exclusão. Além disso, penso que, se o caso sempre foi tratado como uma curiosidade pouco relevante, isso decorre, em grande parte, da já mencionada ausência da perspectiva de gênero como ferramenta de análise e de problematização nesses estudos.
22 - A exclusão de gênero no lugar da pesquisa e da escrita da história no Brasil do século XIX se manteve por mais de 120 anos. Somente em 1965, o IHGB admitiu a primeira sócia, a historiadora Virginia Rau, incialmente no quadro de correspondentes portugueses, e, em 1968, entre os sócios efetivos, admitiu a geógrafa Isa Adonias (WEHLING 2010, p. 179).

23 - Caso emblemático durante o período de criação da Academia Brasileira de Letras ( $A B L)$, o nome da escritora Júlia Lopes de Almeida foi indicado por Lúcio Mendonça para integrar o quadro de fundadores. O veto à sua elegibilidade se deu sob a alegação de que a agremiação, ainda embrionária, seguiria o modelo de sua congênere francesa, cujo regulamento restringia a candidatura aos indivíduos do sexo masculino. Em 1911, a filóloga de origem alemã radicada em Portugal, Carolina Michaëlis, seria indicada para uma vaga de correspondente, tendo seu nome vetado sob o pretexto pouco convincente de que, naquele momento, encontrava-se preenchida a cota de membros correspondentes portugueses (FANINI 2010). 


\section{Gênero, memória e esquecimento disciplinar}

Não foram poucas as advertências de Joan W. Scott (1992, 2008, 2011) quanto à condição ambígua da história das mulheres como espécie de suplemento inócuo à história geral, assinalando que o potencial crítico e desestabilizador do feminismo seria desperdiçado caso não encontrássemos um caminho para pensar teoricamente sobre as relações dos estudos de gênero com a disciplina histórica. ${ }^{24}$ Há mais de 30 anos, a historiadora entendia que, mais do que explicar a expansão dos chamados women's studies como mero reflexo da chamada segunda onda feminista, era fundamental considerar o seu impacto na própria política de produção do conhecimento histórico, o que implicava uma crítica mais radical das suas bases conceituais e premissas epistemológicas (SCOTT 1992, p. 66 e 94). Ora, a história ascendeu ao estatuto de prática profissional especializada sob o preceito de se oferecer como "investigação desinteressada, imparcial e universalmente disponível" para todos os que comprovassem domínio de seus protocolos de pesquisa (SCOTT 1992, p. 71). Alinhados a essa ambição, os critérios de inclusão e exclusão da corporação dos historiadores assentam-se em processos de avaliação de competências nos quais os marcadores identitários sociais como gênero, raça e classe seriam, aparentemente, irrelevantes.

No entanto, a presença das mulheres na academia e, por conseguinte, de praticantes do ofício do sexo feminino, não deixaria de evidenciar uma experiência compartilhada de discriminação baseada em diferenças de gênero. Mesmo submetidas a padrões comuns de avaliação da "excelência" e do desempenho, as historiadoras passariam a formular demandas particulares que não poderiam ser subordinadas àquelas da categoria geral, e supostamente "universal", dos historiadores (SCOTT 1992, p. 69).

Evidentemente, as observações de Scott estiveram baseadas, em grande parte, no cenário universitário norteamericano posterior aos anos 1970, marcado pela presença

24 - É importante lembrar que o artigo seminal de Scott, "Gender: a useful category of historical analysis", foi publicado originalmente na American Historical Review, em dezembro de 1986, e reimpresso no livro da historiadora, Gender and the politics of History, de 1988. 
das historiadoras feministas que passaram a contestar os padrões profissionais dominantes que se consubstanciavam na figura universal do historiador como indivíduo branco do sexo masculino (SCOTT 1992, p. 74). ${ }^{25}$ Naquele contexto, as praticantes dos chamados women's studies estariam à frente da crítica ao campo acadêmico profissional dominante, a suas divisões e hierarquias disciplinares, a seus critérios de autoridade científica e fundamentos epistêmicos (HEILBORN; SORJ 1999, p. 185). A historiografia feminista tenderia a tornar menos delimitada a oposição entre "prática profissional" e "militância política" na medida em que colocaria em questão as relações de poder sobre as quais as normas e protocolos disciplinares da história estão edificados.

No entanto, como destacou Scott, a oposição entre política e profissionalismo conseguiu pouco a pouco obscurecer as implicações epistemológicas mais radicais da perspectiva feminista, implicações essas nas quais residiria uma das principais contribuições da historiografia feminista (SCOTT 1992, p. 72). É possível perceber como o impacto epistêmico da teoria feminista foi rapidamente amortecido na recepção à história escrita pelas historiadoras feministas. Neste caso, os historiadores "tradicionais" não deixaram de exercer o seu poder de guardiões da disciplina, aplicando o rótulo de "ideologia" ao que consideraram a produção distorcida por considerações de gênero dessas historiadoras, em contraponto ao que eles defendiam como sendo o conhecimento histórico obtido por meio de uma investigação neutra e isenta (SCOTT 1992, p. 79). Argumento similar serviu de base, por exemplo, para os comentários críticos que Robert Finlay dirigiu a Natalie Zemon Davis em um artigo publicado na American Historical Review, de 1988, acusando-a de desprezar a "soberania das fontes" e transgredir "o tribunal da documentação", por meio de uma leitura excessivamente "imaginativa" e com viés "feminista" da vida de Martin Guerre (FINLAY apud SCOTT 1992, p. 80).

Não por acaso, oito anos antes do célebre estudo sobre o retorno de Martin Guerre, Davis (1980) publicara um texto

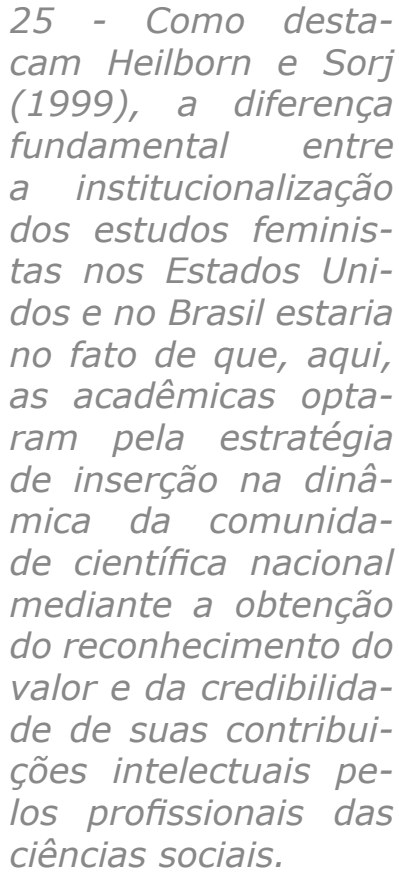

ciências sociais. 
seminal sobre gênero feminino, gênero literário e a escrita da história por mulheres intitulado "Gender and genre: women as historical writers, 1400-1820". Oito anos depois, no ensaio denso intitulado "History's two bodies" (1988), inspirado no célebre livro de Ernst Kantorowicz, Davis aborda, a partir de três contextos temporais distintos, os modos como historiadores construíram linhagens de filiação, transmissão e sucessão intelectual. Antes de analisar as relações de colaboração entre Marc Bloch e a medievalista inglesa Eillen Power, nos anos 1920, Davis assinala que o time interdisciplinar da primeira geração dos Annales era uma "confraria de irmãos franceses" composta por editores homens. A principal exceção no grupo dos fundadores era Simone Vidal Bloch, esposa de Bloch, que atuava como secretária assistente e revisora de todos os seus manuscritos e cujo trabalho nunca foi reconhecido ou sequer mencionado pelo autor de Apologia à História (DAVIS 1988, p. 23). A biógrafa de Bloch, Carole Fink, chega a mencionar uma quantidade abundante de notas de pesquisa, todas manuscritas por Simone Bloch (DAVIS 1988).

Apesar das numerosas resenhas dedicadas a obras de autoria feminina, entre 1929 e 1944, apenas duas historiadoras tiveram trabalhos publicados na revista dos Annales, o que, no entanto, não lhes garantiu nenhuma visibilidade póstuma. A primeira, Thérèse Sclafert, francesa, concluiu o doutorado na Universidade de Paris em 1926, publicou um artigo sobre rotas de comércio medieval no número inaugural da revista. A outra, retirada do esquecimento graças ao estudo de Peter Schöttler (1992 e 2000), ao artigo mencionado de Natalie Davis (1992) e, mais recentemente, a uma página na Wikipedia francesa e ao breve texto em português de Jougi Guimarães para o site do Café História, chamava-se Lucie Varga (1904-1941); três artigos e seis resenhas suas foram publicadas na revista entre 1936 e 1937.

Considerada por Schöttler como "a face oculta dos Annales", com um papel mediador decisivo na construção da rede intelectual dos fundadores do movimento com a produção 
historiográfica alemã, Varga faleceu prematuramente após uma vida marcada pelo exílio e pela luta contra o nazismo. Austríaca de família judia e formada na Universidade de Viena, Varga chegou a Paris em 1933, trabalhou como secretária e tradutora assistente para Febvre e foi sua colaboradora intelectual, fazendo anotações a partir da bibliografia em língua alemã para a pesquisa do historiador sobre a heresia. A edição mais politicamente engajada da revista - a de 1937, dedicada a estudos sobre a Alemanha - contou com uma importante participação da historiadora, que assinou a apresentação do dossiê e dois artigos, um sobre a gênese do nacional-socialismo e outro sobre a juventude hitlerista. A anexação da Áustria à Alemanha, em 1938, obrigou-a a prover o seu sustento e o de sua filha sem o apoio da família austríaca. Varga tentou seguir a carreira acadêmica, além de outras atividades, trabalhando como representante comercial e operária de fábrica. Em meio a tantas dificuldades, publicou um romance, em formato de folhetim, no periódico socialista L'Oeuvre. Em 1939, casou-se pela terceira vez, motivo pelo qual garantiu a naturalização francesa que a salvaria da deportação quando a França foi derrotada na guerra em 1940. Trabalhou como tradutora até estourar o conflito mundial e, depois da desastrosa campanha francesa, viu-se obrigada a migrar com a filha para Toulouse, no sul da França. Lá, buscou a sobrevivência dando aulas de alemão e fazendo trabalhos agrícolas. Por toda essa instabilidade vivida em seus últimos anos pagou um preço alto com sua saúde física, vindo a falecer em abril de 1941, aos trinta e seis anos de idade.

A biografia trágica de Lucie Varga, que resultou em uma carreira intelectual precocemente interrompida, não deveria obscurecer o fato de que ela foi a única mulher a publicar trabalhos expressivos nos primeiros números dos Annales. Até se tornar objeto do estudo de Schöttler, e conforme ele mesmo destaca, ninguém havia visto, lido ou sequer indagado acerca do papel de Varga na fase inicial do movimento (SCHÖTTLER 1992, p. 101).

Trata-se, portanto, de um caso exemplar de esquecimento e apagamento da produção intelectual feminina da memória 
disciplinar, ou seja, do próprio ordenamento narrativo em que se baseia a identidade da disciplina histórica, constituída através de um corpo canônico de textos de autoria masculina cuja autoridade é assegurada não apenas por mecanismos de reconhecimento e consagração entre os próprios historiadores profissionais, mas também por meio do ensino e da difusão pública. Afinal, quantos estudantes de graduação em História ousariam duvidar do que seus professores convictamente Ihes ensinaram sobre o papel "revolucionário" da confraria masculina da historiografia francesa que se consolidou na linhagem que inclui desde Bloch, Febvre, Braudel a Le Goff? Não são esses historiadores comumente apresentados como os verdadeiros "heróis" e pais fundadores de uma forma "nova" de se fazer a história - mesmo que algumas dessas "novidades" já acumulem boas décadas de existência (YAMASHITA 2017) e impliquem certos ocultamentos?

\section{Escrita de autoria feminina e gêneros de história}

Como já destaquei, fora da história da historiografia, os estudos literários, sob o impacto das teorias feministas, a partir dos anos 1970, cumpriram papel decisivo para a visibilidade da produção letrada e intelectual de autoria feminina. Um dos efeitos importantes da crítica literária feminista, especialmente em sua vertente anglo-americana, foi o questionamento da legitimidade do cânone que define o que é ou pode ser considerado literário ou não, bem como a problematização dos paradigmas e estratégias interpretativas da crítica literária tradicional (HOLLANDA 1994, p. 11-12). Esse questionamento se fez acompanhar de um trabalho de arqueologia literária que promoveu o resgate da produção letrada feminina que, sob diversas formas, foi silenciada e excluída das histórias da literatura.

No Brasil, foram os estudos literários que tornaram conhecidas escritoras, poetisas e jornalistas brasileiras do século XIX. ${ }^{26} \mathrm{O}$ corpo canônico historiográfico que se constitui
26 - Entre outros, ver HOLLANDA; ARAÚJO 1993; MUZART 2000 e 2003; TELLES 2012; e DUARTE 1995 e 2003. 
a partir desse período, no entanto, não inclui nomes femininos porque, a rigor, as mulheres não produziam a modalidade de textos reconhecidos ou enquadráveis como "históricos" naquele momento. Assim, por uma dupla determinação de gênero, a constituição da história como disciplina e prática científica na modernidade seria efeito do processo que, na medida em que delimitou os protocolos da historiografia e da pesquisa profissionais, também deixou nas margens, não apenas outras formas de escrita histórica, mas também outros sujeitos possíveis da operação historiográfica (EPPLE; SCHASER 2009).

Em Gender of History, Bonnie Smith definiu como "amadora" a escrita da história praticada por mulheres (que incluía gêneros textuais como ensaios e biografias, romances, memórias e crônicas históricas) desde, pelo menos, o século XVIII (SMITH 2003, p. 95). A francesa Germaine de Stäel seria o grande modelo inspirador para a linhagem das escritoras amadoras da história, da qual fariam parte as inglesas Margaret Fuller, Lydia Maria Child, as norte-americanas Mercy Otis Warren, Hannah Adams, entre outras. Nesse contexto, a crítica literária sempre abordou os escritos de autoria feminina, de modo geral, como exemplos de "inspiração virtuosa, patriótica e moral" afinados ao republicanismo e ao civismo (SMITH 2003, p. 88). Também é possível identificar, nesse período, entre os séculos XVIII e XIX, uma "historiografia sentimental", nos termos de Angelika Schaser (2007), fortemente marcada por interpretações moralizantes do passado e da vida social. Essa forma de historiografia, praticada por escritoras como Sophie Mereau e Johanna Schopenhauer, foi imediatamente rotulada de ingênua e diletante.

No Brasil dos anos finais do século XIX, não por acaso, foi com o adjetivo de "amadora" que a escritora baiana Ignez Sabino (1853-1911) definiu a sua escrita no prefácio do livro Contos e lapidações, de 1891:

Não escrevo para matar o tempo: não escrevo para traduzir pensamentos ligeiros e fúteis, não. Eu escrevo por necessidade moral, física, psicológica e intelectual. Não tenho a pretensão de ser impecável, não tenho a veleidade de julgar-me talento 
quando estou abaixo da mediocridade. Eu escrevo como uma obscuríssima amadora, por isso sejam benévolos para comigo [...] (SABINO 1891, p. 309).

Por trás da explícita tópica da modéstia, estava uma mulher branca, da elite letrada, que, no conturbado contexto da Primeira República, publicou contos, poesias, romances, artigos e ensaios para jornais, além de um volume de breves biografias intitulado Mulheres ilustres do Brasil, que, em suas palavras, pretendia tirar as mulheres de letras brasileiras da "barbárie do esquecimento". Em vida, Sabino não deixaria de ser reconhecida por sua "vasta ilustração", "educação esmerada" e pela "máscula energia de sua ativa pena" (ORLANDO 1996 [1899]). Talvez por conta de suas incursões na prática de gêneros considerados "menores", como a biografia histórica, não conseguiu escapar do contumaz apagamento da memória contra o qual tanto se empenhou: seu nome talvez seja apenas mais um dos listados no rol de mulheres (um pouco mais de uma centena) que escreveram e publicaram textos de modalidades variadas no Brasil do século XIX (MUZART 2003).

\section{Consideraçōes finais: paradoxos e interpelaçōes}

Procurei demonstrar como, a despeito de certa visibilidade advinda de algumas pesquisas recentes, a tradição do silêncio dos sujeitos subalternos se estendeu para o campo de pesquisas da história intelectual, promovendo a marginalização e o ocultamento da produção letrada de autoria feminina, baseados na naturalização dos pressupostos e das determinações de valor implicados na construção dos cânones literários e historiográficos. Neste sentido, identificase nos estudos de literatura o impacto mais expressivo das teorias feministas para reverter o quadro, ainda que o trabalho crítico tenha se concentrado, em grande parte, na denúncia da ideologia patriarcal e nas leituras revisionistas dos cânones. Em suma, subjacente a esses estudos, persiste uma lógica de complementação, na medida em que concentrando-se no 
trabalho de resgate e de memória, continuam tributários dos mesmos pressupostos da tradição androcêntrica que pretendem denunciar (RICHARD 2002).

Na área da História, os limites da efetividade crítica e subversiva da teoria feminista remetem ao impasse apontado por Joan W. Scott quando argumentou que a potência desestabilizadora da categoria de gênero deveria ser usada para se questionar teoricamente as bases epistêmicas da própria disciplina. No caso específico dos estudos de história intelectual, os silêncios em relação às determinações de gênero podem ser explicados por suas conexões diretas com as assimetrias advindas das diferenças de sexo, raça e classe social que estruturam a divisão geopolítica do trabalho intelectual no campo da produção do conhecimento e que, por conseguinte, incidem na demarcação de todos os a priori epistêmicos. Nunca será excessivo assinalar que a pesquisa histórica, como as demais pesquisas nas ciências humanas, é um espaço constituído por hierarquias de poder, de prestígio e de influência que conformam disputas nem sempre explícitas entre modelos teóricos e agendas de investigação que, de modo predominante, são oriundos dos centros metropolitanos do chamado Norte global e difundidos por autores europeus e estadunidenses, o que, nos espaços periféricos, configura a chamada "dependência acadêmica" (CONNELL 2016, p. 18). Ora, como bem observou Ana Carolina Pereira, o desafio maior que se apresenta, especialmente para a teoria da história e caberia acrescentar - para a história intelectual praticadas no Sul global, estaria em uma tarefa anterior à própria possibilidade de superação, demandando o próprio reconhecimento e o exame crítico dessa tendência à extroversão acadêmica como um problema (PEREIRA 2018, p. 109).

Assim, no horizonte mais imediato, os debates em torno da opção decolonial (MIGNOLO; WALSH 2018) e das noções de colonialidade de gênero e de feminismo decolonial (LUGONES 2008 ; 2015) despontam como interpelações dirigidas aos silêncios e apagamentos na história intelectual para as quais todas as tentativas de resposta ainda parecem provisórias e imprevisíveis. ${ }^{27}$

\begin{abstract}
27 - Sob o impacto dos estudos pós-coloniais, merece destaque a abordagem recente da história da historiografia em perspectiva global/transnacional, com ênfase na problematização dos condicionamentos eurocêntricos e etnocêntricos das representações do passado e nas dinâmicas das relações de centro e periferia na produção do conhecimento histórico. Para uma discussão importante, ver SANTOS; NICODEMO; PEREIRA 2017.
\end{abstract}


Como primeiro movimento nesse sentido, as questões de raça, gênero e sexualidade, mais do que temas de estudo a serem sumariamente "domesticados" como tópicos suplementares pelas disciplinas instituídas, de modo a não ameaçarem as suas certezas epistêmicas, demandam um enfrentamento efetivo em sua dimensão propriamente política (VARIKAS 2016, p. 42).

Permanece paradoxal, contudo, que a crescente incorporação da perspectiva de gênero nas ciências humanas ainda seja acompanhada de uma resistência difusa, difícil de ser identificada, que se manifesta como a falta do uso mais radical dessa categoria para se repensar a validade pretensamente universal dos pressupostos epistêmicos das disciplinas. Ademais, como uma das evidências mais imediatas da "guetização" desses estudos, observa-se que, nos cursos de História, a problemática das relações de gênero mantémse como tema de disciplinas eletivas ou complementares, o que, por um lado, corrobora o interesse crescente nessa área de pesquisa (com profusão quantitativa e qualitativa de produção historiográfica, de periódicos especializados, grupos de pesquisa, eventos, etc.), mas, por outro, demonstra certa "particularidade" de seu conteúdo, ainda tido como "específico" demais para ser plenamente integrado aos currículos oficiais ou dotado de centralidade no plano institucional (VARIKAS 1994; 2016). ${ }^{28}$ Assim, embora ninguém mais duvide de que as mulheres possuem a sua própria história, esses estudos se mantêm, em grande parte, como conteúdos transversais e suplementares, submetidos à ordem narrativa do que Eleni Varikas chamou de "território acolhedor e profundamente androcêntrico" da história social (VARIKAS 1994, p. 72). Assim, há a "História" e, paralelamente, a "história das mulheres" e os "estudos de gênero", que permanecem localizados naquela região que Simone de Beauvoir chamou de o "Outro", porque carregam a marca da diferença e o estigma da particularidade (BORDO 2000, p. 11).

Para concluir, retomo a cena da aula de História em Becos da memória, de Conceição Evaristo, destacada na epígrafe, que
28 - Neste sentido, uma pesquisa recente apontou para a invisibilidade das mulheres brasileiras nos livros didáticos de História para o ensino médio avaliados pelo Programa Nacional do Livro Didático do Ministério da Educação (PNLD/ MEC) 2015, constatando que o tema aparece nessas obras, de modo geral, relegado a um domínio separado da narrativa e de seus conteúdos principais (MONTEIRO 2016). Para além do sistema educacional, cabe destacar a avaliação recente de Küchemann, Bandeira e Almeida de que "boa parte das políticas públicas não considera a condição de gênero como estruturadora do campo das relações sociais e dos comportamentos humanos, mas como um acessório opcional das ações dos indivíduos, portanto um aspecto particular, um adesivo que pode ou não ser incorporado à análise geral" (KÜCHEMANN; BANDEIRA; ALMEIDA 2015, p. 78). 
me remeteu à questão sobre as possibilidades de romper com a condição de "sujeito historicamente emudecido da mulher subalterna". Na literatura feita não somente pela escrita, mas pela escrevivência, a história da personagem-narradora, a menina negra nascida e criada na favela, pode se (con)fundir com a história de vida da autora. Aqui, a questão de gênero torna-se mais problemática porque permanece inevitavelmente cruzada com os marcadores de raça e de classe social. A mulher de cor, nas palavras de Gloria Anzaldúa, "é invisível no mundo dominante dos homens brancos e no mundo feminista das mulheres brancas" (ANZALDÚA 2000, p. 229). Ou, ainda, a interseção entre raça, classe e gênero cria "seres impossíveis", na expressão de Maria Lugones: "mulheres não brancas, negras, mestiças, indígenas ou asiáticas são impossíveis porque não são nem mulheres burguesas europeias, nem machos negros ou indígenas" (LUGONES 2014, p. 942). Portanto, nestes casos, as histórias escritas precisam mudar de figura, de forma e de gênero radicalmente, para romper silêncios e apagamentos duradouros.

\section{REFERÊNCIAS BIBLIOGRÁFICAS}

ALEKSIÉVITCH, Svetlana. A guerra não tem rosto de mulher. Traduzido por Cecília Rosas. São Paulo: Companhia das Letras, 2016.

ALMEIDA, Sandra R. Goulart. Intervenções feministas: póscolonialismo, poder e subalternidade. Estudos Feministas, Florianópolis, 21(2):336, p. 689-700, maio-ago. 2013.

ANZALDÚA, Gloria. Falando em línguas: uma carta para as mulheres escritoras do terceiro mundo. Estudos Feministas, ano 8, p. 229-236, 2000 [1981].

ARANHA, Patrícia. Geografia como profissão: campo, auto-representação e historiografia (1934-1955). Rio de Janeiro: Programa de Pós-Graduação em História Social/ UFRJ, 2017. 
ARAÚJO, Valdei L. de. O Direito à História: $O(A)$ Historiador(a) como Curador(a) de uma experiência histórica socialmente distribuída. In: GUIMARÃES, Géssica; BRUNO; PEREZ, Rodrigo. Conversas sobre o Brasil: ensaios de crítica histórica. Rio de Janeiro: Autografia, 2017, pp. 191-216.

BAHRI, Deepika. Feminismo e/no pós-colonialismo. Estudos Feministas, Florianópolis, v. 21, n. 2, p. 659-688, maioago. 2013.

BALLESTRIN, Luciana M. Aragão. Feminismos subalternos. Estudos Feministas, v. 25, n. 3, p. 1035-1054, set.dez. 2017.

BERNARDES, Maria Thereza C. C. Mulheres de ontem? Rio de Janeiro, século XIX. São Paulo: T. A. Queiroz editor, 1988.

BETIM, Felipe. ABL frustra expectativas de campanha por Conceição Evaristo e elege Cacá Diegues. El País, 31 de ago. 2018. Disponível em: https://brasil.elpais. com/brasil/2018/08/30/cultura/1535658767_015684.html Acesso em: agosto 2018.

BORDO, Susan. A feminista como o outro. Estudos Feministas, ano 8, p. 10-29, $1^{\circ}$. semestre de 2000.

BRANCO, Lucia Castello. O que é escrita feminina. São Paulo: Brasiliense, 1991.

BOURDIEU, Pierre. A dominação masculina. $5^{a}$ ed. Traduzido por Maria Helena Kühner. Rio de Janeiro: Bestbolso, 2017.

BUTLER, Judith. Problemas de gênero: feminismo e subversão da identidade. $10^{\mathrm{a}}$ ed. Traduzido por Renato Aguiar. Rio de Janeiro: Civilização Brasileira, 2016.

Undoing gender. N. York: Routledge, 2004. 
CERTEAU, Michel de. L'histoire, science et fiction. Paris: Gallimard, 1987.

CHARPENEL, Marion. Les enjeux de la mémoire chez les historiennes des femmes, 1970-2001. Actes de la Recherche en Sciences Sociales, n. 223, p. 12-25, 2018.

CONNEL, Raewyn. Gênero em termos reais. Traduzido por Marília Moschkovich. São Paulo: nVersos, 2016.

CORREA, Marisa. Antropólogas e antropologia. Belo Horizonte: Editora UFMG, 2003.

DAVIS, Natalie Z. History's Two Bodies. The American Historical Review, v. 93, n. 1, p. 1-30, 1988. Women and the World of the "Annales". History Workshop, n. 33, p. 121-137, 1992.

DOSSE, François. Histoire intellectuelle. In: DELACROIX, C. et. all. (dir.) Historiographies I: concepts et débats. Paris: Gallimard, 2010, p. 378-390.

DUARTE, Constância L. Imprensa feminina e feminista no Brasil: século XIX. Belo Horizonte: Autêntica, 2017.

EPPLE, Angelika; SCHASER, Angelika. Gendering historiography: beyond national canons. Frankfurt/N. York: Campus Verlag, 2009.

EVARISTO, Conceição. Becos da memória. Rio de Janeiro: Pallas, 2017.

FANINI, Michele Asmar. A (in)elegibilidade feminina na Academia Brasileira de Letras. Tempo Social, v. 22, n. 1, p. 149-177, jun. 2010.

FÚKS, Julian. Prefácio. In: ELTIT, Diamela. Jamais o fogo nunca. Traduzido por Julián Fúks. Belo Horizonte: Editora Relicário, 2017. Disponível em: https://medium.com/@ 
relicarioedicoes/prólogo-de-julián-fuks-para-jamais-ofogo-nunca-de-diamela-eltit-b69b38ca3c48). Acesso em: agosto 2018.

GREVER, Maria; STUURMAN, Siep (ed.). Beyond the canon: History for the twenty-first century. New York: Palgrave Macmillan, 2007.

GUIMARÃES, Lúcia Maria Paschoal. Debaixo da imediata proteção de Sua Majestade Imperial: o Instituto Histórico e Geográfico Brasileiro (1838-1889). RIHGB, Rio de Janeiro, ano 156, n. 388, p. 459-613, jul.-set., 1995.

GUIMARÃES, Manoel Luiz Salgado. A cultura histórica oitocentista: a constituição de uma memória disciplinar. In: PESAVENTO, Sandra J. História cultural: experiências de pesquisa. Porto Alegre: UFRGS Editora, 2003, p. 9-24.

HEILBORN, M. Luiza; SORJ, Bila. Estudos de gênero no Brasil. In: MICELI, Sergio (org.) O que ler na Ciência Social brasileira (1970-1995). São Paulo: Ed. Sumaré; ANPOCS; Brasília: CAPES, 1999, p. 183-221.

HOLLANDA, Heloisa B.; ARAÚJO, Lucia N. Ensaístas brasileiras. Rio de Janeiro: Rocco, 1993.

HOLLANDA, Heloisa B. (org.) Tendências e impasses: o feminismo como crítica da cultura. Rio de Janeiro: Rocco, 1994.

KEATING, Ana Louise (ed.). Introduction. In: Gloria Anzaldua reader. Durham and London: Duke University Press, 2009, pp. 1-15.

KÜCHEMANN, Berlindes; BANDEIRA, Lourdes M.; ALMEIDA, Tânia Mara C. A categoria de gênero nas Ciências Sociais e sua interdisciplinaridade. Revista do Ceam, v. 3, n. 1, p. 63-81, jan.-jun. 2015.

LANDER, Edgardo (org.) A colonialidade do saber: eurocentrismo e ciências sociais - perspectivas latino- 
americanas. Buenos Aires: Clacso, 2005.

LUGONES, Maria. Colonialidad y gênero. Tabula Rasa, n. 9, p. 73-101, jul.-dic., 2008.

LUGONES, Maria. Rumo a um feminismo descolonial. Estudos Feministas, v. 22, n. 3, p. 935-952, set.-dez., 2014 [2010].

MENDEZ, Natalia P. Intelectuais feministas no Brasil dos anos 1960: Carmen da Silva, Heleieth Saffioti e Rose Marie Muraro. São Paulo: Paco Editorial, 2018.

MIGNOLO, Walter; WALSH, Catherine E. On decoloniality: concepts, analytics, praxis. Durham and London: Duke University, 2018, p. 33-56.

MONTEIRO, Paolla Ungaretti. (In)visibilidade das mulheres brasileiras nos livros didáticos de História do Ensino Médio (PNLD, 2015). Porto Alegre: PUC-RS Programa de Pós-Graduação em Educação, 2016.

MUZART, Zahidé L. Escritoras Brasileiras do século XIX. Florianópolis: Mulheres; Santa Cruz do Sul: EDUNISC, 2003.

OLIVEIRA, M. da Glória de. Fazer história, escrever a história: sobre as figurações do historiador no Brasil oitocentista. Revista Brasileira de História, v. 30, n. 59, p. 37-52, 2010.

OLIVEIRA, M. da Glória de. Escrever vidas, narrar a história: a biografia como problema historiográfico no Brasil oitocentista. Rio de Janeiro: FGV Editora, 2011.

ORLANDO, Arthur. Carta à leitora. In: SABINO, Ignez. Mulheres illustres do Brasil. Edição fac-similar. Florianópolis: Editora das Mulheres, 1996 [1899], p. xi-xviii.

PEDRO, Joana Maria. Relações de gênero como categoria transversal na historiografia contemporânea. Topoi, v. 12, 
n. 22, p. 270-283, jan.-jun. 2011.

PELEGRIN, Nicole. Histoires d'historiennes. Saint Étienne: Publications I'Université de S. Étienne, 2006.

PEREIRA, Ana Carolina Barbosa. Precisamos falar sobre lugar epistêmico na Teoria da História. Tempo e Argumento, v. 10, n. 24, p. 88-114, abr.-jun., 2018.

PRIORE, Mary del (org.) História das mulheres do Brasil. $7^{a}$ ed. São Paulo: Contexto, 2004.

QUIJANO, Aníbal. Colonialidad del poder y clasificación social. Journal of world-systems research, v. 11, n. 2, p. 342-386, 2000.

RACINE, Nicole; TREBITSCH, Michel (dir.) Intellectuelles: du genre em histoire des intellectuels. Bruxelles: Éditions Complexe, 2004.

RICHARD, Nelly. A escrita tem sexo? In: RICHARD, Nelly. Intervenções críticas. Traduzido por Romulo Montes Alto. Belo Horizonte: Editora UFMG, 2002.

RILEY, Denise. "Am I that name?" Feminism and the category of "women" in History. Minneapolis: University of Minnesota Press, 1995.

SABINO, Ignez. Contos e lapidações. Rio de Janeiro: Laemmert Editores, 1891.

SABINO, Ignez. Mulheres illustres do Brasil. Edição facsimilar. Florianópolis: Editora das Mulheres, 1996 [1899].

SALES, Véronique (org.). Os historiadores. Traduzido por Christiane G. Colas. São Paulo: Unesp, 2011.

SANTOS, Pedro A. C. dos; NICODEMO, Thiago L.; PEREIRA, Mateus $\mathrm{H}$. de Faria. Historiografias periféricas em perspectiva global ou transnacional: eurocentrismo em 
questão. Estudos Históricos, v. 30, n. 60, p. 161-186, jan.-abr., 2017.

SCHASER, Angelika. The challenge of gender: national historiography, nationalism and national identities. In: QUATAERT, Jean H.; HAGEMANN, Karen (ed.) Gendering modern German History: rewriting historiography. New York: Berghan Books, 2007.

SCHÖTTLER, Peter. Lucie Varga: les autorités invisibles. Une historienne autrichienne aux Annales dans les années trente. Paris: Le Cerf, 1991.

SCHÖTTLER, Peter. Lucie Varga: a central European refugee in the circle of French Annales, 1934-1941. History Workshop Journal, Issue 33, p. 100-120, 1992. Disponível em: http://smjegupr.net/wp-content/uploads/2012/05/ Schöttler-Peter.-Lucie-Varga-A-Central-EuropeanRefugee-in-the-Circle-of-the-French-"Annales"-1934-1941. pdf Acesso em: agosto 2018.

SCOTT, Joan W. História das mulheres. In: BURKE, P. (org.) A escrita da História: novas perspectivas. São Paulo: UNESP, 1992, p. 63-95.

SCOTT, Joan W. Unanswered questions. AHR Forum: revisiting "Gender: a useful category of historical analysis". American Historical Review, v. 113, Issue 5, dec. 2008.

SCOTT, Joan W. The fantasy of feminist history. Durham and London: Duke University, 2011.

SEGATO, Rita L. Gênero e colonialidade: em busca de chaves de leitura e de um vocabulário estratégico descolonial. e-cadernos ces, 2012. Disponível em: http://eces.revues. org/1533 Acesso: ago. 2018.

SHOWALTER, Elaine. A crítica feminista no território selvagem. In: HOLLANDA, Heloisa B. (org.) Tendências e impasses: o feminismo como crítica da cultura. Rio de 
Janeiro: Rocco, 1994, p. 23-57.

SILVA, Joaquim Norberto de Sousa. Crítica reunida: 1850-1892. Porto Alegre: Nova Prova Editora, 2005.

SMITH, Bonnie C. Gênero e história: homens, mulheres e a prática histórica. Bauru/SP: EDUSC, 2003 [1998].

SMITH, Hilda L. Women Intellectuals and Intellectual History: their paradigmatic separation. Women's History Review, v. 16, n. 3, p. 353-368, 2007.

SPIVAK. G. C. Pode o subalterno falar? Traduzido por Sandra Regina G. Almeida; Marcos P. Feitosa e André P. Feitosa. Belo Horizonte: Editora UFMG, 2014.

\section{REVISTA DO INSTITUTO HISTÓRICO E GEOGRÁFICO}

BRASILEIRO. Rio de Janeiro, Tomo LV, 1892.

TELLES, Norma. Encantações: escritoras e imaginação literária no Brasil, século XIX. São Paulo: Intermeios, 2012.

TURIN, Rodrigo. Uma nobre, difícil e útil empresa: o ethos do historiador oitocentista. História da Historiografia, n. 2, p. 12-28, mar. 2009.

TURIN, Rodrigo. História da historiografia e memória disciplinar: reflexões sobre um gênero. História da Historiografia, n. 13, p. 78-95, dez. 2013.

VARIKAS, Eleni. Gênero, experiência e subjetividade: a propósito do desacordo Tilly-Scott. Cadernos Pagu, n. 3, p. 63-84, 1994.

VARIKAS, Eleni. Pensar o sexo e o gênero. Traduzido por Paulo Sérgio de Souza Jr. Campinas: Editora da Unicamp, 2016.

VOVELLE, Michel (org.). Os historiadores. Lisboa: Editorial Teorema, 2005. 
YAMASHITA, Jougi G. Lucie Varga: a "desconhecida" historiadora dos Annales. 3 de jul. 2017. Disponível em:https://www.cafehistoria.com.br/lucie-varga-e-osannales/ Acesso em: maio 2018.

WALSH, Catherine E. Insurgency and the decolonial prospect, praxis and project. In: MIGNOLO, Walter; WALSH, Catherine E. On decoloniality: concepts, analytics, praxis. Durham and London: Duke University, 2018, p. 33-56.

WEHLING, Arno. De formigas, aranhas e abelhas. Reflexões sobre o IHGB. Rio de Janeiro: IHGB, 2010.

WOOLF, Daniel. Uma História global da história. Petrópolis: Vozes, 2014.

WOOLF, Virgínia. Profissões para mulheres e outros artigos feministas. Traduzido por Denise Bottmann. Porto Alegre: LPM Editora, 2012.

\section{AGRADECIMENTOS E INFORMAÇŌES}

\section{Maria da Glória de Oliveira}

E-mail: mgloriaprof@gmail.com

Doutorado em História Social/UFRJ UFRRJ

A primeira versão deste texto foi apresentada no encontro A História (in) disciplinada - teoria, ensino e difusão do conhecimento histórico, Porto Alegre/UFRGS. Os ajustes posteriores incorporaram os comentários valiosos de Rebeca Gontijo, Ana Carolina Barbosa Pereira, Benito Schmidt, Flávia Varella, Rodrigo Turin e Pedro Caldas. 